\title{
ANALISIS KUALITAS LAYANAN SISTEM INFORMASI AKADEMIK UNIVERSITAS ABDURRAB TERHADAP KEPUASAN PENGGUNA MENGGUNAKAN METODE SEVQUAL (Studi Kasus : Mahasiswa Universitas Abdurrab Pekanbaru)
}

\author{
Yuni Septiani' ${ }^{1)}$, Edo Arribe ${ }^{2)}$, Risnal Diansyah ${ }^{3)}$ \\ 1,2,3) Sistem Informasi dan Universitas Muhammadiyah Riau Jl. KH. Ahmad Dahlan No. 88, \\ Sukajadi, Pekanbaru, Telp : (0761) - 35008, Fax : (0761) - 20497 \\ Email : yuniseptiani52@gmail.com, edoarribe@umri.ac.id,risnal@umri.ac.id
}

\begin{abstract}
Academic Information System is the name of an information system used for academic activities at Abdurrab University and also known as SIMAK. Abdurrab University has been implementing Academic Information Systems since 2016, but in the application of this system there are still some obstacles so that it will affect what is to be achieved, one of which is user satisfaction. In this study the method used is the Service Quality method with measurements based on dimensions of service quality which include Tangible, Reliability, Responsibility, Assurance and Empathy. The purpose of this study was to determine how much influence the quality of Academic Information Systems on user satisfaction using the Servqual method with the IBM SPSS Statistics 24.0 tool. This research is a quantitative research using survey method. The technique in sampling in this study is to use nonprobability techniques or using the Quota Sampling Technique. In this case the formula used in sampling is the Slovin formula, so this study obtained a sample size of 96 respondents. Based on the evaluation results it can be concluded that the Empathy variable significantly influences user satisfaction by 44.8\%, while simultaneously Tangible, Reliability, Responsiveness, Assurance and Empathy variables together have a significant influence on user satisfaction at the significance level $\alpha$ $=10 \%$
\end{abstract}

Keywords : Service Quality, User Satisfaction, Academic Information Systems, Servqual Method

\begin{abstract}
Abstrak
Sistem Informasi Akademik adalah nama dari sebuah sistem informasi yang digunakan untuk kegiatan akademik pada Universitas Abdurrab dan di kenal juga dengan nama SIMAK. Universitas Abdurrab telah menerapkan Sistem Informasi Akademik sejak tahun 2016, namun pada penerapan sistem ini masih terdapat beberapa kendala sehingga akan berpengaruh dengan apa yang ingin dicapai, salah satunya yaitu kepuasan pengguna. Pada penelitian ini metode yang digunakan yaitu metode Service Quality dengan pengukuran berdasarkan dimensi kualitas pelayanan yang meliputi Tangible, Reliability, Responsibility, Assurance Dan Empathy. Tujuan dari penelitian ini adalah untuk mengetahui seberapa besar pengaruh kualitas Sistem Informasi Akademik terhadap kepuasan pengguna dengan menggunakan metode Servqual dengan alat bantu IBM SPSS Statistics 24.0. Penelitian ini merupakan penelitian yang bersifat penelitian kuantitatif dengan menggunakan metode survey. Teknik dalam pengambilan sampel pada penelitian ini yaitu menggunakan Teknik nonprobability atau menggunakan Teknik Quota Sampling. Dalam hal ini rumus yang digunakan dalam pengambilan sampel adalah rumus Slovin, sehingga penelitian ini didapatkan jumlah sampel sebanyak 96 responden. Berdasarkan hasil evaluasi maka didapatkan kesimpulan bahwa variabel Empathy berpengaruh signifikan terhadap kepuasan pengguna sebesar $44,8 \%$, sedangkan secara simultan variabel Tangible, Reliability, Responsiveness, Assurance dan Emphaty bersama-sama memiliki pengaruh yang signifikan terhadap kepuasan pengguna pada tingkat signifikansi $\alpha=10 \%$.
\end{abstract}

Kata kunci : Kualitas Layanan, Kepuasan Pengguna, Sistem Informasi Akademik, Metode Servqual 


\section{PENDAHULUAN}

\subsection{Latar Belakang}

Di era globalisasi saat ini teknologi informasi berkembang sangat pesat, kini informasi menjadi sangat mudah untuk di akses oleh seluruh pengguna, salah satunya pemanfaatan internet yang sangat luas dalam kehidupan manusia. Penggunaan teknologi informasi adalah salah satu tujuan agar bisa bersaing dan berlomba-lomba dalam memberikan pelayanan akademik yang terbaik. Dengan adanya teknologi informasi yang dikembangkan oleh berbagai institusi pendidikan menjadi sebuah sistem informasi akademik yang dapat diakses secara online oleh pengguna. Pemanfaatan teknologi informasi dalam dunia akademik telah banyak digunakan oleh institusi pendidikan, terutama institusi yang ada di Indonesia khususnya di Provinsi Riau seperti Universitas Islam Negeri Sultan Syarif Kasim, Universitas Riau, Universitas Muhammadiyah Riau dan Universitas Abdurrab Pekanbaru.

Universitas Abdurrab merupakan salah satu perguruan tinggi swasta yang ada di Pekanbaru. Universitas Abdurrab bermula dari Chest Clinic yang merupakan cikal-bakal dari Rumah Sakit Profesor Tabrani pada Tahun 1979. Selanjutnya berturut-turut pada Tahun 1996 dibuka Akademi Perawatan (AKPER), Akademi Analis Farmasi dan Makanan (AKAFARMA) Tahun 1999, Akademi Fisioterapi (AKFIS) Tahun 2002 dan Akademi Kebidanan (AKBID) Tahun 2002 oleh Yayasan Abdurrab. Universitas Abdurrab dibina dibawah naungan Yayasan Fajar dan Yayasan Iqra Annisa. Perguruan tinggi ini didirikan pada tahun 2005 dengan izin Menteri Pendidikan Nasional RI No.75/D/0/2005 dan berdasarkan surat Dirjen Dikti Depdiknas RI No.2128/D/T/2 tanggal 11 Juli 2008 secara resmi keluar izin menyelenggarakan Program Studi S1 Pendidikan Dokter pada Universitas Abdurrab.

Saat ini Universitas Abdurrab telah menerapkan Sistem Informasi Akademik yang dikenal dengan SIMAK yang sudah digunakan sejak tahun 2016. Sistem Informasi Akademik adalah salah satu perangkat lunak yang digunakan untuk menyajikan informasi dan menata administrasi perguruan tinggi yang berhubungan dengan kegiatan akademik yang ada di dalamnya. Dengan penggunaan perangkat lunak seperti ini diharapkan kegiatan administrasi akademik dapat dikelola dengan baik dan informasi yang diperlukan dapat diperoleh dengan mudah dan cepat (Jogianto, 2005). Tujuan penerapan sistem tersebut adalah untuk membantu proses layanan akademik di Universitas Abdurrab dan memudahkan pengguna dalam mengakses informasi Akademik.

Sistem Informasi Akademik Universitas Abdurrab digunakan oleh Mahasiswa, Dosen, Administrasi Program Studi dan Administrasi Akademik. Fitur yang terdapat dalam sistem ini adalah mahasiswa dapat melihat informasi akademik, jadwal perkuliahan, riwayat perkuliahan, pengisian KRS, mencetak KHS dan mencetak Transkip Nilai. Dosen juga dapat meng-input nilai mahasiswa dan melihat informasi akademik. Sementara Admin Program Studi bertugas untuk pengaturan jadwal, pembuatan paket perkuliahan, penjadwalan paket matakuliah, pengelolaan pembimbing akademik, pengelolaan nilai mahasiswa, pengelolaan informasi jurusan dan pengelolaan berkas jurusan. Sedangkan Admin Akademik bertugas untuk pengelolaan kurikulum mata kuliah, pengelolaan data dosen, pengelolaan data mahasiswa, pengelolaan mahasiswa transfer dan pengelolaan kalender akademik. Meskipun penerapan Sistem Informasi Akademik telah diterapkan di Universitas Abdurrab namun masih terdapat beberapa kendala dalam penggunaannya, salah satunya yaitu kendala tentang kepuasan mahasiswa dalam penggunaan sistem tersebut.

Permasalahan yang terjadi dalam penggunaan Sistem Informasi Akademik Universitas Abdurrab tentang kepuasan mahasiswa dalam penggunaan sistem yaitu kurang update-nya sistem tentang pengumuman atau pemberitahuan yang telah di keluarkan oleh pihak 
Universitas, tidak adanya pemberitahuan tentang pengambilan matakuliah semester atas bagi mahasiswa yang SKS-nya telah mencukupi, nilai mahasiswa yang sudah di input pada semester sebelumnya hilang atau tidak timbul pada semester selanjutnya sehingga menyebabkan nilai Indeks Prestasi Kumulatif tidak valid atau tidak sesuai.

Permasalahan yang telah dijelaskan diatas dapat menghambat proses layanan yang diberikan kepada pengguna, sehingga pengguna akan merasa kurang puas dengan kualitas layanan yang telah diberikan. Dengan demikian kita perlu menganalisis sejauh mana kualitas layanan yang diberikan kepada pengguna. Dalam menganalisis suatu sistem informasi banyak metode yang dapat digunakan salah satunya yaitu metode service quality atau yang sering dikenal dengan servqual. Metode Servqual merupakan metode pengukuran kualitas pelayanan yang paling banyak digunakan dan dikembangkan dengan maksud untuk membantu para manajer dalam menganalisis suumber masalah kualitas dan memahami caracara memperbaiki kualitas layanan (Tjiptono : 2008). Dengan metode servqual ini kita dapat mengukur sejauh mana kualitas layanan Sistem Informasi Akademik Universitas Abdurrab sehingga mampu memberikan kepuasan kepada penggunanya. Kepuasan pengguna merupakan salah satu faktor keberhasilan dalam implementasi sistem informasi. Untuk mengetahui apakah sistem ini sudah sesuai dengan harapan pengguna maka perlu dilakukan analisis kualitas layanan sistem informasi yang telah diterapkan pada Universitas Abdurrab.

Berdasarkan latar belakangpermasalahan diatas, maka penulis bermaksud untuk melakukan penelitian dengan mengangkat sebuah judul "Analisis Kualitas Layanan Sistem Informasi Akademik Universitas Abdurrab Terhadap Kepuasan Pengguna Menggunakan Metode Servqual'.

\section{TINJAUAN PUSTAKA}

\subsection{Pengertian Analisis}

Menurut Komaruddin (2001:53) Pengertian analisis adalah kegiatan berpikir untuk menguraikan suatu keseluruhan menjadi komponen sehingga dapat mengenal tanda-tanda komponen, hubungannya satu sama lain dan fungsi masing-masing dalam satu keseluruhan yang terpadu. Menurut Harahap dalam (Azwar, 2019) Pengertian analisis adalah memecahkan atau menguraikan sesuatu unit menjadi unit terkecil.

Dari pendapat diatas dapat ditarik kesimpulan bahwa analisis merupakan suatu kegiatan berfikir untuk menguraikan atau memecahkan suatu permaslaahan dari unit menjadi unit terkecil.

\subsection{Pengertian Kualitas Layanan}

Menurut Kotler (2005 : 153) Kualitas layanan adalah model yang menggambarkan kondisi pelanggan dalam bentuk harapan akan layanan dari pengalaman masa lalu, promosi dari mulut ke mulut, dan iklan dengan membandingkan pelayanan yang mereka harapkan dengan apa yang mereka terima atau rasakan.

Menurut Nasution dalam (Ramadita, 2015) kualitas pelayanan adalah upaya pemenuhan kebutuhan dan keinginan pelanggan, serta ketetapan penyampaiannya untuk mengimbangi harapan pelanggan. Juga dijelaskan bahwa kualitas layanan adalah tingkat keunggulan yang diharapkan oleh pengendalian atas tingkat keunggulan tersebut untuk memenuhi keinginan pelanggan. Kualitas pelayanan bukan dilihat dari sudut pandang pihak penyelanggara atau pihak penyedia layanan, melainkan berdasarkan persepsi pelanggan, karena pelangganlah yang mengkonsumsi dan merasakan pelayanan yang diberikan sehingga merekalah yang seharusnya menilai dan menentukan kualitas pelayanan. 
Menurut Yamit dalam (Ramadita, 2015) menyatakan bawa ada beberapa pengertian yang terkait dengan definisi kualitas layanan, yaitu :

1. Excellent adalah standart kinerja pelayanan yang diperoleh

2. Customer adalah perorangan, kelompok, departement atau perusahaan yang siterima, membayar output pelayanan

3. Service adalah kegiatan utama atau pelengkap yang tidak secara langsung terlibat dalam proses pembuatan produk, tetapi lebih menekankan pada pelayanan transaksi antara pembelian dan penjual

4. Quality adalah sesuatu yang secara khusus dapat diraba atau tidak dapat diraba dari sifat yang dimiliki produk atau jasa

5. Levels adalah suatu pernyataan atas sistem yang digunakan untuk memonitor dan mengevaluasi

6. Consistent adalah tidak memiliki variasi dan semua pelayanan berjalan sesuai standart yang telah ditetapkan

7. Delivery adalah memberikan pelayanan yang benar dengan cara yang benar dan dalam waktu yang tepat

Parasuraman dalam (Ramadita, 2015) menjelaskan bahwa ada dua faktor yang dapat mempengaruhi kualitas pelayanan, yaitu :

1. Perceived Service

Perceived Service terjadi apabila jasa yang diterima atau dirasakan pelanggan sesuai dengan harapan, maka kualitas jasa dipersepsikan baik dan memuaskan.

2. Expected Service

Expected Service terjadi apabila jasa yang diterima melampaui harapan pelanggan, maka kualitas jasa dipersepsikan sebagai kualitas ideal.

Dari beberapa pendapat tentang kualitas layanan di atas dapat disimpulkan bahwa kualitas layanan adalah upaya untuk memenuhi segala keinginan dan kebutuhan pelanggan sehingga ketetapan penyampaiannya dapat mengimbangi harapan pelanggan.

\subsection{Service Quality}

Menurut Tjiptono dalam (Mira Khozanah, 2016) Metode Servqual merupakan metode pengukuran kualitas pelayanan yang paling banyak digunakan dan dikembangkan dengan maksud untuk membantu para manajer dalam menganalisis sumber masalah kualitas dan memahami cara-cara memperbaiki kualitas layanan.

Dari pendapat di atas dapat disimpulkan bahwa servqual merupakan suatu metode yang digunakan untuk mengukur kualitas layanan yang diberikan kepada pelanggan, menganalisis masalah kualitas serta mengetahui bagaimana cara untuk memperbaiki kualitas layanan yang telah diberikan kepada pelanggan.

Metode ini kembangkan oleh Zeithaml (1990 dikutip oleh Tjiptono, 2008) menggunakan pendekatan user-based approach, yang mengukur kualitas jasa secara kuantitatif dalam bentuk kuesioner dan mengandung dimensi-dimensi kualitas jasa yaitu tangibles, reability, responsiveness, assurance dan emphaty. Metode ini secara garis besar terbagi menjadi 2 bagian yaitu :

1. Bagian ekspektasi, yang memuat pertanyaan-pertanyaan untuk mengetahui dengan pasti ekspektasi atauharapanumumdari pelanggan/pengguna terhadap sebuah jasa.

2. Bagian persepsi, yang memuat petanyaan-pertanyaan untuk mengukurpersepsi pelanggan/pengguna tentang pelayanan jasa yang diberikan oleh suatu perusahaan dengan kategori tertentu. 


\subsection{Dimensi Servqual}

Setelah mengetahui apa yang dimaksud dengan Service Quality (Servqual) maka kita harus mengetahui apa saja dimensi yang termasuk di dalam Servqual. Berdasarkan hasil penelitian terhadap beberapa jenis jasa, Berry dan Parasuraman dalam (fitzsimmons, 1995, dikutip oleh Tjiptono, 2008) berhasil mengidentifikasi lima kelompok karakteristik yang digunakan oleh para pelanggan atau pengguna dalam mengevaluasi kualitas jasa, yaitu :

1. Tangibles (bukti nyata), menggambarkan fasilitas fisik, perlengkapan, dan tampilan dari personaliaserta kehadiran para pengguna

2. Reliability (keandalan), merujuk pada kemampuan untuk memberikan pelayanan yang dijanjikan secara akurat dan handal.

3. Responsiveness (daya tanggap), yaitu kesediaan untuk membantu pelanggan serta memberikan perhatian yang tepat.

4. Assurance(jaminan),merupakan karyawan yang sopan dan berpengetahuan luas yang memberikan rasa percaya serta keyakinan.

5. Empathy (empati) mencakup kepedulian serta perhatian individual kepada para pengguna.

\subsection{Teknik Pengambilan Sampel}

Ada dua cara pengambilan sampel, yaitu dengan teknik probabilitas (Probability Sampling) dan sampel non-probabilitas (Non-Probability Sampling).

1. Sampel Probabilitas (Probability Sampling) adalah teknik pengambilan sampel yang memberikan peluang yang sama kepada setiap anggota populasi untuk menjadi sampel. Teknik ini meliputi :

a. Simple Random Sampling adalah teknik yang paling sederhana (simple). Sampel diambil secara acak, tanpa memperhatikan tingkatan yang ada dalam populasi, tiap elemen populasi memiliki peluang yang sama dan diketahui untuk terpilih sebagai subjek.

b. Startifed Random Sampling adalah teknik yang membantu menaksir parameter populasi, mungkin terdapat sub kelompok elemen yang bisa diidentifikasi dalam populasi yang dapat diperkirakan memiliki parameter yang berada pada suatu variabel yang diteliti.

c. Proportionate Stractifed Random Sampling adalah teknik yang hampir sama dengan simple random sampling namun penentuan sampelnya memerhatikan strata (tingkatan) yang ada dalam populasi.

d. Disproportionate Stratified Random Sampling adalah teknik yang hampir mirip dengan proportionatestratifiedrandom sampling dalam hal heterogenitas populasi.Namun ketidakprofesionalan dalam penentuan sampel didasarkan pada pertimbangan jika anggota populasi berstrata umum namun kurang proposional pembagiannya.

e. Cluster Sampling atau sampel kelompok digunakan jika sumber data atau populasi sangat luas.

2. Sampel Non-probabilitas (Non- probability Sampling) adalah teknik pengambilan sampel dimana setiap anggota populasi tidak memiliki kesempatan atau peluang yang sama sebagai sampel. Digunakan apabila representasi/keterwakilan sampel tidak penting. Teknik yang termasuk kedalam non-probability ini antara ini antara lain :

a. Systematic Sampling adalah teknik samplingyang menggunakan nomor urut dari populasi baik yang berdasarkan nomor yang ditetapkan sendiri oleh peneliti maupun nomor identitas tertentu, ruang dengan urutan yang seragam atau pertimbangan sistematis lainnya. 
b. Quota Sampling adalah teknik sampling yang menentukan jumlah sampel dari populasi yang memiliki ciri tertentu sampai jumlah kuota yang diinginkan.

c. Convenience Sampling adalah Sampel dengan pertimbangan kemudahan merupakan teknik penentuan sampel berdasarkan kemudahan saja. Seseorang diambil sebagai sampel karena kebetulan orang tersebut ada di tempat atau kebetulan mengenal orang tersebut. Secara kebetulan, atau siapa saja yang kebetulan bertemu dengan peneliti yang dianggap cocok dengan karakteristik sampel yang akan ditentukan sampel.

d. Purposive Sampling merupakan teknik penentuan sampel dengan pertimbangan khusus sehingga layak dijadikan sampel.

e. Boring Sampling adalah sampel yang mewakili jumlah populasi. Biasanya dilakukan jika populasi dianggap kecil atau kurang dari 100, lebih sering di sebut total sampling.

f. Showball Sampling adalah teknik penarikan sampel yang mula -mula dilakukan dalam jumlah kecil (informasi kecil) kemudian sampel yang terpilih pertama disuruh memilih sampel berikutnya, yang akhirnya jumlah sampel akan bertambah banyak seperti bola salju yang bergelinding makin lama makin besar.

\section{METODOLOGI PENELITIAN}

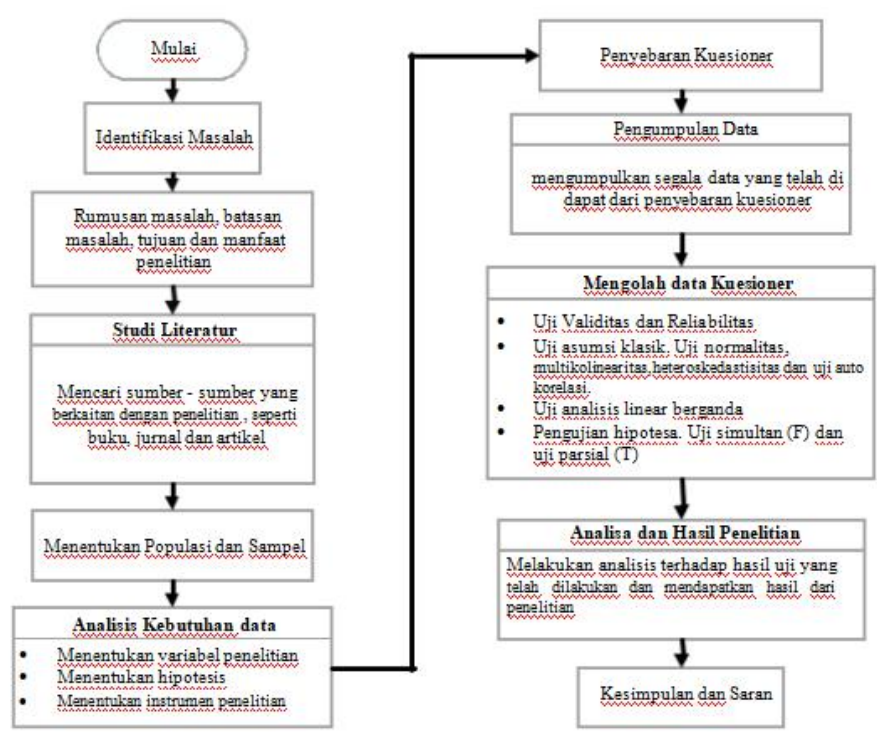

Gambar 3.1 Proses dan Alur Penelitian

\section{HASIL PENELITIAN DAN PEMBAHASAN}

\subsection{Instrumen Penelitian}

Berikut adalah instrumen penelitian yang akan digunakan dalam mengumpulkan data. Peneliti akan menggunakan 30 pernyataan berdasarkan Servqual dan menggunakan Skala Likert dalam mengukur setiap pernyataan yang disajikan kepada responden. Skala pengukuran yang dipakai dalam kuesioner ini adalah Skala Likert. 
Tabel 4.1 Skala Likert

\begin{tabular}{lc}
\hline Bobot/Skala & Keterangan \\
\hline 1 & Sangat Setuju (SS) \\
2 & Setuju (S) \\
3 & Netral (N) \\
4 & Tidak Setuju (TS) \\
5 & Sangat Tidak Setuju (STS) \\
\hline
\end{tabular}

Perancangan pernyataan dalam kuesioner diambil dari indikator yang telah di tentukan dalam Servqual. Dalam penelitian ini peneliti menggunakan 25 indikator variabel (X) yang terdiri dari Tangible/ Bukti Nyata (X1), Reliability/ kehandalan (X2), Responsiveness/ Daya Tanggap (X3), Assurance/ Jaminan (X4), Empathy/ Empati (X5) dan 5 indikator dari variabel (Y). Jadi didapatlah jumlah indikatornya yaitu sebanyak 30 pernyataan.

\subsection{Analisa Responden}

Dalam tahap analisa data responden ini terbagi menjadi 3 tahap, yaitu :

a. Pengambilan sampel menggunakan sampel non-probability dengan menggunakan metode teknik Convenience Sampling.

b. Responden dari penelitian ini adalah Mahasiswa Universitas Abdurrab dengan jumlah 2441 Mahasiswa. Penentuan Populasi dan Sampel menggunakan rumus Slovin untuk mewakili populasi sebagai berikut :

$\mathrm{n}=$

Keterangan :

$\mathrm{n}=$ Ukuran Sampel

$\mathrm{N}=$ Jumlah Populasi

$\mathrm{e}=$ Taraf kesalahan $(10 \%)$

$\mathrm{N}=2441$

$\mathrm{e}=10 \%=0.1$

$\mathrm{n}=$

$\mathrm{n}=$

$\mathrm{n}=96.06$

c. Pertanyaan yang di buat dalam bentuk kuesioner adalah berupa pertanyaan megenai tentang sistem yang ada di Universitas Abdurrab, pelayanan sistem serta kepuasan pengguna. 
JURNAL TEKNOLOGI DAN OPEN SOURCE

\subsection{Karakteristik Responden}

\section{a. Berdasarkan Program Studi}

\section{Karakteristik Program Studi}

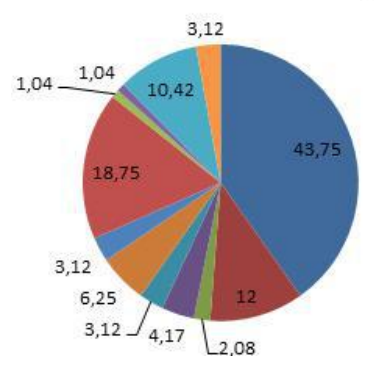

a fisioterapi

narmasi

Enafarma

a kebidanan

- keperawatan

- pendidikan dokter

- ilmu pemerintahan

- ilmu komunikasi

\section{b. Berdasarkan Jenis Kelamin}

\section{Karakteristik Jenis Kelamin}

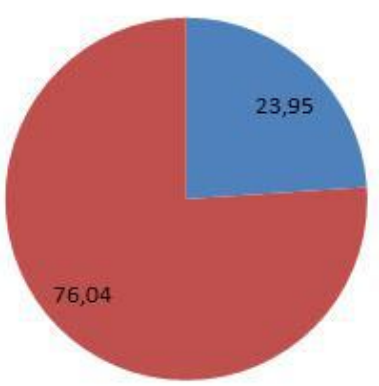

$$
\text { - Laki-laki }
$$

- Perempuan

\subsection{Uji Kelayakan Kuesioner}

\section{Uji Vaiditas}

\begin{tabular}{ccccc}
\hline Variabel & Pernyataan & R hitung & R tabel & Keterangan \\
\hline Tangible & $\mathrm{X} 1.1$ & 0,839 & 0,168 & Valid \\
(Bukti Nyata) & $\mathrm{X} 1.2$ & 0,835 & 0,168 & Valid \\
& $\mathrm{X} 1.3$ & 0,817 & 0,168 & Valid \\
& $\mathrm{X} 1.4$ & 0,823 & 0,168 & Valid \\
& $\mathrm{X} 1.5$ & 0,846 & 0,168 & Valid \\
\hline Variabel & Pernyataan & $\mathrm{R}$ hitung & $\mathrm{R}$ tabel & Keterangan \\
\hline Keliability & $\mathrm{X} 2.1$ & 0,850 & 0,168 & Valid \\
& $\mathrm{X} 2.2$ & 0,831 & 0,168 & Valid \\
& $\mathrm{X} 2.3$ & 0,891 & 0,168 & Valid \\
& $\mathrm{X} 2.4$ & 0,889 & 0,168 & Valid \\
& $\mathrm{X} 2.5$ & 0,869 & 0,168 & Valid
\end{tabular}


JURNAL TEKNOLOGI DAN OPEN SOURCE

VOL. 3 No. 1, Juni 2020 : 131 - 143

\begin{tabular}{|c|c|c|c|c|}
\hline Variabel & Pernyataan & R hitung & $R$ tabel & Keterangan \\
\hline Responsiveness & $\mathrm{X} 3.1$ & 0,837 & 0,168 & Valid \\
\hline (Cepat & $\mathrm{X} 3.2$ & 0,863 & 0,168 & Valid \\
\hline \multirow[t]{3}{*}{ Tanggap) } & $\mathrm{X} 3.3$ & 0,857 & 0,168 & Valid \\
\hline & $\mathrm{X} 3.4$ & 0,925 & 0,168 & Valid \\
\hline & X3.5 & 0,894 & 0,168 & Valid \\
\hline Variabel & Pernyataan & R hitung & $\mathrm{R}$ tabel & Keterangan \\
\hline Assurance & $\mathrm{X} 4.1$ & 0,896 & 0,168 & Valid \\
\hline (Jaminan/ & $\mathrm{X} 4.2$ & 0,870 & 0,168 & Valid \\
\hline \multirow[t]{3}{*}{ Kepastian) } & $\mathrm{X} 4.3$ & 0,874 & 0,168 & Valid \\
\hline & $\mathrm{X} 4.4$ & 0,880 & 0,168 & Valid \\
\hline & $\mathrm{X} 4.5$ & 0,97 & 0,168 & Valid \\
\hline Variabel & Pernyataan & R hitung & R tabel & Keterangan \\
\hline Empathy & X5.1 & 0,880 & 0,168 & Valid \\
\hline \multirow[t]{4}{*}{ (Empati) } & $\mathrm{X} 5.2$ & 0,915 & 0,168 & Valid \\
\hline & $\mathrm{X} 5.3$ & 0,924 & 0,168 & Valid \\
\hline & X5.4 & 0,780 & 0,168 & Valid \\
\hline & $\mathrm{X} 5.5$ & 0,918 & 0,168 & Valid \\
\hline Variabel & Pernyataan & R hitung & R tabel & Keterangan \\
\hline Kepuasan & Y.1 & 0,921 & 0,168 & Valid \\
\hline \multirow[t]{4}{*}{ Pengguna } & $\mathrm{Y} .2$ & 0,907 & 0,168 & Valid \\
\hline & Y.3 & 0,900 & 0,168 & Valid \\
\hline & Y.4 & 0,921 & 0,168 & Valid \\
\hline & Y.5 & 0,913 & 0,168 & Valid \\
\hline
\end{tabular}

\section{$\underline{\text { Uji Reliabilitas }}$}

\begin{tabular}{|c|c|c|c|}
\hline \multirow{3}{*}{ Cases } & Valid & 96 & 100,0 \\
\hline & Excluded ${ }^{3}$ & 0 &, 0 \\
\hline & Total & 96 & 100,0 \\
\hline \multicolumn{4}{|c|}{$\begin{array}{l}\text { a. Listwise deletion based on all variables in the } \\
\text { procedure. }\end{array}$} \\
\hline
\end{tabular}

Tabel 4.26 hasil reliabilitas variabel Tangible

\begin{tabular}{l} 
Reliability Statistics \\
Cronbach's N of Items \\
Alpha \\
\hline, 781
\end{tabular}

E-ISSN : 2622-1659

P-ISSN : 2655-7592

Tabel 4.27 case processing summary

\begin{tabular}{llrr}
\hline \multicolumn{4}{c}{ Case Processing Summary } \\
& & \multicolumn{2}{c}{$\%$} \\
\hline \multirow{3}{*}{ Cases } & Valid & 96 & 100,0 \\
& Excluded & 0 &, 0 \\
& Total & 96 & 100,0
\end{tabular}

a. Listwise deletion based on all variables in the procedure.

Tabel 4.28 hasil reliabilitas variabel Reliability

Reliability Statistics

Cronbach's $\mathrm{N}$ of Items

Alpha

\begin{tabular}{ll}
\hline, 915 & 5
\end{tabular}

Tabel 4.29 case processing summary

\begin{tabular}{llrr}
\hline \multirow{4}{*}{ Case Processing Summary } \\
& & \multicolumn{2}{c}{$\%$} \\
\hline \multirow{3}{*}{ Cases } & Valid & 96 & 100,0 \\
& Excluded $^{3}$ & 0 &, 0 \\
& Total & 96 & 100,0
\end{tabular}

a. Listwise deletion based on all variables in the procedure.

Tabel 4.30 hasil reliabilitas variabel Responsiveness

Reliability Statistics

Alpha

\begin{tabular}{l}
\hline $924 \quad 5$ \\
\hline
\end{tabular}

Tabel 4.31 case processing summary

\begin{tabular}{llrr}
\hline \multicolumn{4}{c}{ Case Processing Summary } \\
& \multicolumn{3}{c}{$\%$} \\
\hline \multirow{4}{*}{ Cases } & Valid & 96 & 100,0 \\
& Excluded & 0 & 0 \\
& Total & 96 & 100,0 \\
a. Listwise deletion based on all variabies in the \\
procedure.
\end{tabular}

Tabel 4.32 hasil reliabilitas variabel Assurance

Reliability Statistics

Cronbach's N of Items

Alpha

$931 \quad 5$


JURNAL TEKNOLOGI DAN OPEN SOURCE

VOL. 3 No. 1, Juni 2020 : 131 - 143

Tabel 4.33 case processing summary

\begin{tabular}{|c|c|c|c|}
\hline & \multicolumn{3}{|c|}{ Case Processing Summary } \\
\hline & & $N$ & $\%$ \\
\hline & Valid & 96 & 100,0 \\
\hline \multirow[t]{2}{*}{ Cases } & Excluded $^{a}$ & 0 &, 0 \\
\hline & Total & 96 & 100,0 \\
\hline \multicolumn{4}{|c|}{$\begin{array}{l}\text { a. Listwise deletion based on all variables in the } \\
\text { procedure. }\end{array}$} \\
\hline
\end{tabular}

Tabel 4.34 hasil reliabilitas variabel Assurance

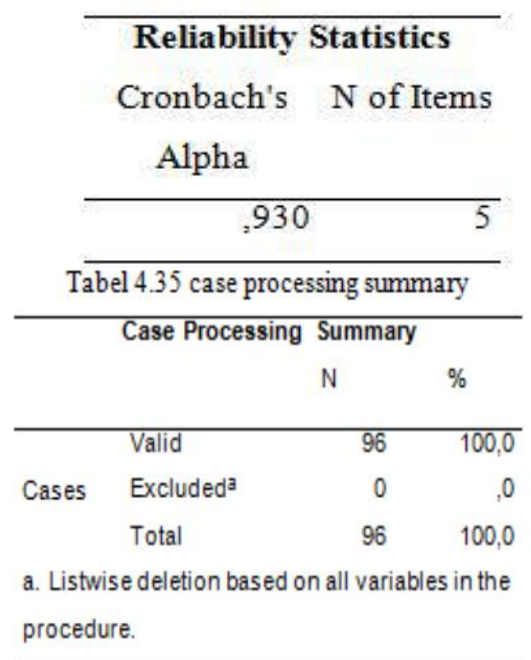

Tabel 4.36 hasil reliabilitas variabel Kepuasan Pengguna

\begin{tabular}{ll}
\hline \multicolumn{2}{c}{ Reliability Statistics } \\
$\begin{array}{c}\text { Cronbach's } \\
\text { Alpha }\end{array}$ & N of ltems \\
\hline & \\
\hline 949 & 5
\end{tabular}

\subsection{Uji Asumsi Klasik}

\section{Uji Normalitas}

\begin{tabular}{llr}
\hline \multicolumn{2}{c}{ One-Sample Kolmogorov-Smirnov Test } \\
& $\begin{array}{r}\text { Unstandardiz } \\
\text { ed Residual }\end{array}$ \\
\hline $\mathrm{N}$ & $\begin{array}{r}96 \\
\text { Noman }\end{array}$ &, 0000000 \\
& Std. & 1,75021331 \\
Most Extreme & Deviation &, 194 \\
Differences & Positive &, 099 \\
Kolmogorov-Smirnov Z & Negative &,- 194 \\
Asymp. Sig. (2-tailed) & 1,897 \\
a. Test distribution is Normal. &, 002 \\
b. Calculated from data. & \\
\hline
\end{tabular}

\section{E-ISSN : 2622-1659}

P-ISSN : 2655-7592

Dari hasil uji normalitas menggunakan metode KolmogorovSmirnov didapatkan hasil signifikan dari uji normalitas sebesar 0.002 di mana hasil tersebut lebih besar dari taraf signifikansi, sehingga dapat disimpulkan bahwa uji tes normalitas pada penelitian ini adalah terdistribusi normal.

\section{$\underline{\text { Uji Multikoleniaritas }}$}

\begin{tabular}{|c|c|c|c|c|c|c|c|c|}
\hline \multirow{3}{*}{ Mode } & \multicolumn{8}{|c|}{ Coefficients" } \\
\hline & & \multicolumn{2}{|c|}{$\begin{array}{l}\text { Unstandardized } \\
\text { Coefficients }\end{array}$} & \multirow{2}{*}{$\begin{array}{l}\text { Standardized } \\
\text { Coefficients } \\
\text { Beta }\end{array}$} & \multirow[t]{2}{*}{ T } & \multirow[t]{2}{*}{ Sig. } & \multicolumn{2}{|c|}{$\begin{array}{l}\text { Collinearity } \\
\text { Statistics }\end{array}$} \\
\hline & & в & Std. Error & & & & Tolerance & VIF \\
\hline \multirow{6}{*}{1} & (Constant) & $-1,087$ &, 605 & & $-1,796$ &, 076 & & \\
\hline & $\mathrm{x} 1$ & .222 & . 086 & 182 & 2,584 & .011 & .306 & 3.272 \\
\hline & $\mathrm{x} 2$ & ,011 & ,118 & , 011 &, 097 & ,923 &, 123 & 8,155 \\
\hline & $\mathrm{x} 3$ &, 145 & .118 & .151 & 1,231 & .222 & .101 & 9,879 \\
\hline & $\mathrm{x} 4$ & .213 & .083 & .211 & 2,578 & .012 & .227 & 4,399 \\
\hline & $\mathrm{x} 5$ & ,444 & ,096 & ,448 & 4,616 & ,000 &, 162 & 6,18 \\
\hline \multicolumn{9}{|c|}{ a. Dependent Variable: $Y$} \\
\hline
\end{tabular}

Berdasarkan tabel diatas maka diketahui untuk variabel (X1) memiliki nilai tolerance yaitu 0,306 yang berarti $>$ 0,10 maka tidak terjadi multikolinearitas dan nilai VIF 3,272 yang berarti $<10$ maka tidak terjadi persoalan multikolinearitas diantara variabel bebas. Jika dilihat pada seluruh model dalam penelitian ini maka seluruh variabel bebas tidak terdapat persoalan multikolinearitas.

\section{Uji Heteroskedastisitas}

\begin{tabular}{|c|c|c|c|c|c|c|}
\hline \multirow[b]{2}{*}{ Mad } & \multicolumn{6}{|c|}{ Coefficients } \\
\hline & & \multicolumn{2}{|c|}{ Unstandardized Coefficiénts } & $\begin{array}{l}\text { Standardized } \\
\text { Coefficients } \\
\text { IIBeta? }\end{array}$ & th & Sig: \\
\hline \multirow{7}{*}{1} & & 4032 & $3 \quad 306$ & & 3605 & 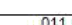 \\
\hline & & & & & & \\
\hline & (1) & $=050$ & $=056$ & $=162$ & +801 & 361 \\
\hline & $x_{2}$ & 084 & 077 & 316 & 1,086: & 280 \\
\hline & $\times 3$ & $4=153$ & 6,077 & -836 & $-1,984$ & 0.50 \\
\hline & $x 4$ & ;069: & 054 & 275 & 1,285 & 202 \\
\hline & $\times 5$ & $068^{\circ}$ & 063 & 274 & 1,081 & 283 \\
\hline & endentVariab & & & & & \\
\hline
\end{tabular}

berdasarkan tabel di atas hasil uji heteroskedastisitas pada penelitian ini dapat di simpulkan bahwa X1, X2, X3, X4 dan X5 tidak mengalami masalah heteroskedastisitas. 


\subsection{Uji Regresi Linear Berganda}

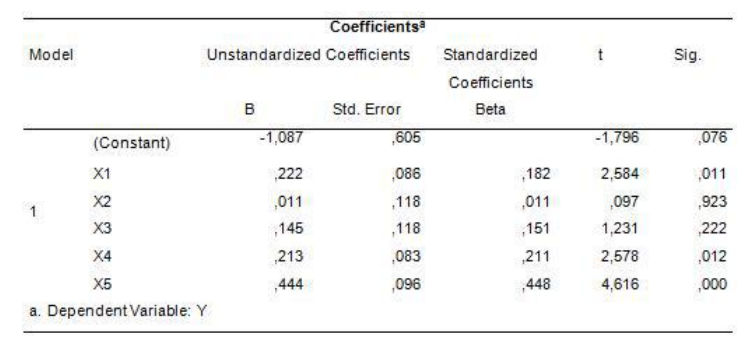

Berdasarkan tabel diatas maka diperoleh model persamaan regresi linier berganda sebagai berikut :

$\mathrm{Y}=\mathrm{a}+\mathrm{b} 1 \mathrm{X} 1+\mathrm{b} 2 \mathrm{X} 2+\mathrm{b} 3 \mathrm{X} 3+\mathrm{b} 4 \mathrm{X} 4+\mathrm{b} 5 \mathrm{X} 5$

$Y=(-1,087)+0,222 X 1+0,011 X 2+0,145 X 3+0,213 X 4+0,444 X 5$

\subsection{Uji Hipotesa}

Uii Simultan (Uii F)

\begin{tabular}{|c|c|c|c|c|c|c|}
\hline \multicolumn{7}{|c|}{ ANOVA ${ }^{8}$} \\
\hline \multicolumn{2}{|c|}{ Model } & Sum of Squares & Df & Mean Square & $F$ & Sig. \\
\hline \multirow{3}{*}{1} & Regression & 1832,950 & 5 & 366,590 & 113,375 &, $0000^{\circ}$ \\
\hline & Residual & 291,008 & 90 & 3,233 & & \\
\hline & Total & 2123,958 & 95 & & & \\
\hline \multicolumn{7}{|c|}{ a. DependentVariable: $Y$} \\
\hline \multicolumn{7}{|c|}{ b. Predictors: (Constant), $\times 5, \times 1, X 4, \times 2, \times 3$} \\
\hline
\end{tabular}

\section{$\underline{\text { Uii Parsial (Uii T) }}$}

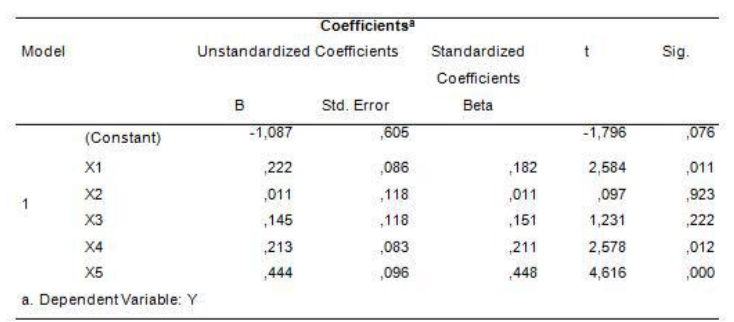

\section{$\underline{\text { Koefisien Determinasi }}$}

\begin{tabular}{|c|c|c|c|c|}
\hline \multicolumn{5}{|c|}{ Model Summary } \\
\hline 1 & $\mathrm{R}$ & $\mathrm{R}$ & Adjuste & Std. \\
\hline \multirow[t]{2}{*}{ odel } & & Square & d R Square & Error of the \\
\hline & & & & Estimate \\
\hline \multirow{2}{*}{1} & 9 & .86 & 855 & 1,798 \\
\hline & $29^{3}$ & \multicolumn{2}{|l|}{3} & \\
\hline \multicolumn{4}{|c|}{ a. Predictors: (Constant), $X 5, X_{1}, X_{4}, X_{2}, X_{3}$} & \\
\hline
\end{tabular}




\section{Kesimpulan dan Saran}

\subsection{Kesimpulan}

Berdasarkan tujuan penelitian yaitu untuk mengetahui pengaruh kualitas layanan pada sistem informasi akademik terhadap kepuasan pengguna yang ada di Universitas Abdurrab Pekanbaru dengan menggunakan metode servqual dan berdasarkan uji yang dilakukan dalam penelitian ini maka dapat di ambil kesimpulan sebagai berikut :

1. Dari hasil uji secara simultan (Uji F) di ketahui nilai signifikansi untuk pengaruh $\mathrm{X} 1, \mathrm{X} 2$, $\mathrm{X} 3, \mathrm{X} 4$ dan X5 secara simultan terhadap $\mathrm{Y}$ adalah sebesar $0,000<0,1$ dan nilai $\mathrm{F}$ hitung 113,375 > F tabel 1,91, sehingga dapat disimpulkan bahwa $\mathrm{H} 1$ diterima yang berarti terdapat pengaruh variabel Tangible (X1), Reliability (X2), Responsiveness (X3), Assurance (X4) dan Empathy (X5) mempunyai pengaruh secara bersama-sama (simultan) terhadap variabel kepuasan pengguna $(\mathrm{Y})$.

2. Dari hasil uji secara parsial (Uji T) diperoleh hasil sebagai berikut :

a. Pada variabel tangible (bukti nyata) diketahui nilai sig. untuk pengaruh $\mathrm{X} 1$ terhadap $\mathrm{Y}$ adalah sebesar $0,011<0,1$ dan nilai $\mathrm{T}$ hitung 2,584 >1,661, sehingga dapat disimpulkan bahwa $\mathrm{H} 20$ di tolak dan $\mathrm{H} 2 \mathrm{a}$ diterima yang berarti terdapat pengaruh Tangible (X1) terhadap kepuasan pengguna (Y).

b. Pada variabel Reliability (keandalan) diketahui nilai sig. untuk pengaruh X1 terhadap $\mathrm{Y}$ adalah sebesar 0,923 $>0,1$ dan nilai $\mathrm{T}$ hitung $0,097<1,661$, sehingga dapat disimpulkan bahwa $\mathrm{H} 20$ di terima dan $\mathrm{H} 2 \mathrm{a}$ ditolak. yang berarti tidak terdapat pengaruh Reliability (X2) terhadap kepuasan pengguna (Y).

c. Pada variabel Responsiveness (cepat tanggap) diketahui nilai sig. untuk pengaruh X1 terhadap $\mathrm{Y}$ adalah sebesar $0,222>0,1$ dan nilai $\mathrm{T}$ hitung $1,231<1,661$, sehingga dapat disimpulkan bahwa $\mathrm{H} 40$ diterima dan $\mathrm{H} 4 \mathrm{a}$ ditolak yang berarti tidak terdapat pengaruh Responsiveness (X3) terhadap kepuasan pengguna (Y).

d. Pada variabel Assurance (jaminan) diketahui nilai sig. untuk pengaruh X1 terhadap Y adalah sebesar $0,012<0,1$ dan nilai $\mathrm{T}$ hitung 2,578 $>1,661$, sehingga dapat disimpulkan bahwa $\mathrm{H} 40$ di tolak dan $\mathrm{H} 4$ a diterima yang terdapat pengaruh Assurance (X4) terhadap kepuasan pengguna (Y).

e. Dan pada variabel Empathy (empati) diketahui nilai sig. untuk pengaruh X3 terhadap $\mathrm{Y}$ adalah sebesar sebesar $0,000<0,1$ dan nilai $\mathrm{T}$ hitung 4,616 $>1,661$, sehingga dapat disimpulkan bahwa $\mathrm{H} 50_{0}$ di tolak dan $\mathrm{H} 5$ a diterima yang berarti terdapat pengaruh Empathy (X5) terhadap kepuasan pengguna (Y)

\subsection{Saran}

Saran yang dapat disampaikan dari penelitian yang telah dilakukan mengenai analisis kualitas layanan sistem informasi (SIMAK) menggunakan metode servqual adalah sebagai berikut :

1. Pimpinan Universitas Abdurrab sebaiknya meningkatkan pelayanan yang ada di Universitas, baik itu layanan akademik maupun administrasi sehingga mahasiswa dapat terlayani dengan baik.

2. Peneliti selanjutnya agar dapat lebih menyempurnakan penelitian yang berhubungan dengan sistem informasi akademik (SIMAK) Universitas Abdurrab Pekanbaru dan menganalisis faktor-faktor lain yang dianggap berpengaruh terhadap kepuasan mahasiswa yang tidak terdapat dalam penelitian ini. 


\section{DAFTAR PUSTAKA}

1. Aryo, T. S dan Harya, B.D. 2014 Analisis Kepuasan Konsumen Dengan Servqual. Jurnal Nasional Sistem informasi Indonesia.

2. Aulia Rahmatun Nisa, Piter Anjas Surbakti. 2018. Teknik Pengambilan Sampel. Makalah. Departemen Statistika. Semarang.

3. Azwar, 2019. Analisis Kualitas Layanan Sistem Manajemen Apartur Responsif Terpadu Menggunakan Metode Servqual. Universitas Muhammadiyah Riau.

4. Fathoni, 2009. "Analisis Kualitas Layanan Sistem Informasi Menggunakan Metode Servqual", Dosen pada Jurusan Sistem Informasi Fakultas Ilmu Komputer Universitas Sriwijaya.

5. Febriany Feibe Rosaline Tuerah. 2015. Analisis Kualitas Layanan Akademik dan Administrasi Terhadap Kepuasan Mahasiswa.Universitas Sam Ratulangi.

6. Fikri Siswaka. 2019. Analisis Kualitas LayananE-CommerceC2C-Classifieds Terhadap Kepuasan Pengguna Menggunakan Metode WebQual .Universitas Muhammadiyah Riau.

7. Hais Dama, 2010, “ Pengaruh Kualitas Pelayanan Terhadap Loyalitas Nasabah Pada Bank Mandiri Cabang Gorontalo" Fakultas Ekonomi Dan Bisnis Universitas Negeri Gorontalo,2 Juni 2010

8. Jogiyanto, H.M. 2005. Pengenalan Komputer. Yogyakarta : Andi.

9. Khusaini, Ahmad. 2016. Analisis kualitas pelayanan terhadap kepuasan konsumen di SPA Club Arena Yogyakarta. Universitas Negeri Yogyakarta.

10. Komaruddin, 2001. Ensilopedia Manajemen, Edisi ke 5, Jakarta, Bumi Aksara.

11. Kotler. 2005. Manajemen Pemasaran. Jilid 1 dan 2. Jakarta. PT.Indeks Kelompok Gramedia.

12. Lina Martati. 2016. Analisis Kualitas Layanan Sistem Informasi Akademi (SIKAD) Menggunakan Metode Servqual. Universitas Islam Riau

13. Margono.2004.Metodologi Penelitian Pendidikan. Jakarta. PT.Rineka Cipta.

14. Marlindawati, 2013, “ Analisis Kualitas Layanan Sistem Informasi Menggunakan Servqual Method", Fakultas Ilmu Komputer Universitas Bina Dharma, Yogyakarta, 15 Juni 2013.

15. Nila Sari Yunita.2018. Analisis Kualitas Pelayanan Terhadap Kepuasan Pelanggan.

16. Ni luh, A. K. 2018. Pengukuran Kepuasan Pengguna Sistem Informasi DosenMenggunakanMetode Servqual. Jurnal Sistem dan Informatika Vol.12 No.2. Hal 19-25

17. Novita Sari, Ritonga. 2019. Analisis kualitas layanan sistem informasi integrated library system (INLIS) lite dengan menggunakan metode ITIL V3. Universitas Muhammadiyah Riau.

18. Nurmaini Dalimunthe, M.Mabrur, dan Saide. 2017. Analisis Kualitas Layanan SIKDA Terhadap Kepuasan Pengguna Dengan Metode Servqual.UIN Suska Riau.

19. Siti Monalisa, Presdi Ponti Anggara, Fitra Kurnia. 2018. Analisis kesuksesan Penerapan sistem Administrasi Akasemik Menggunakan Human Organization Technology Fit Model. UIN Suska Riau.

20. Satria Wijaya. 2017. Analisis Tingkat Kepuasan Mahasiswa Terhadap Pelayanan Bagian Keuangan Dengan Metode Customer Satisfaction Index. Skripsi. STIKOM Bali.

21. Tony D Susanto. 2016. Manajemen Layanan Teknologi Informasi. Aisindo. Surabaya. 